\title{
Assessing The Economic Viability And Fueling Capacity of Renewable Hydrogen: A Way Forward For Green Economic Performance And Policy Measures
}

\section{Baijun Wu ( $1642196168 @ q q . c o m)$}

Chengde Medical University https://orcid.org/0000-0003-1153-1459

Bingfeng Zhai

Chengde Medical University

Huaizi Mu

Chengde Medical University

Xin Peng

Chengde Medical University

Chao Wang

Chengde Medical University

Ataul Karim Patwary

Universiti Utara Malaysia

\section{Research Article}

Keywords: Energy security, Energy efficiency, Renewable hydrogen, Green economic indicators, Renewable energy

Posted Date: May 28th, 2021

DOl: https://doi.org/10.21203/rs.3.rs-454525/v1

License: (c) (i) This work is licensed under a Creative Commons Attribution 4.0 International License. Read Full License 
4

5

6

7

8

9

\section{Assessing the Economic Viability and Fueling Capacity of Renewable} Hydrogen: A way forward for Green Economic Performance and Policy Measures

\author{
1 \\ Baijun Wu \\ Lecturer, Chengde Medical University, \\ Email: 1642196168@qq.com
}

2

Bingfeng Zhai

Lecturer, Chengde Medical University, Email: zhaibingfeng2021@163.com

3

Huaizi Mu

Lecturer, Chengde Medical University, Email: muhuaizi2021@,163.com

4

Xin Peng

Lecturer, Chengde Medical University,

Email: pengxin19902021@163.com

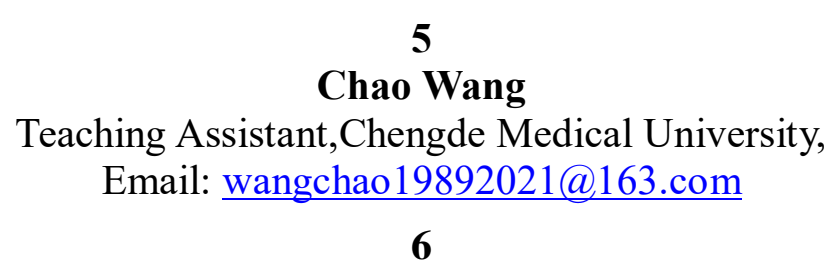

Ataul Karim Patwary

School of Tourism, Hospitality and Event Management, Universiti Utara Malaysia, Malaysia Email: raselataul@gmail.com 
* Corresponding Author: Wu Baijun (1642196168@qq.com)

Chengde Medical University, China

35

\section{Abstract}

Energy security and environmental measurements are incomplete without renewable energy therefore there is a dire need to explore new energy sources. Therefore, the aim of this study is to measure the wind power potential to generate the renewable hydrogen including its production and supply cost. We used first order eneginnering model and net present value to measure the levelized cost of wind generated renewable hydrogen by using the data source of Pakistan metorological department and State bank of Paksitan. Results shows that the use of surplus wind and renewable hydoregn energy for green economic production is suggested as an innovative project option for large-scale hydrogen use. The key annual running expenses for hydrogen are electricity and storage cost, which have a major impact on the costs of renwable hydrogen. Also, the results indicates that project has the potential to cut $\mathrm{CO}_{2}$ pollution by 139 million metric tons and raise revenue for wind power plants by 2998.52 million dollars. The renewable electrolyzer plants avoided $\mathrm{CO}_{2}$ at a rate of 24.9-36.9 \$/ton under baseload service, relative to $44.3 \$$ /ton for the benchmark. However, in the more practical mid-load situation, these plants have a significant benefit. Further, the wind generated renewable hydrogen deliver a $6-11 \%$ larger than annual rate of return than the standard $\mathrm{CO}_{2}$ catch plant due to their capacity to remain running and supply hydrogen to the consumer through periods of plentiful wind and heat. Also, the measured levelized output cost of hydrogen $(\mathrm{LCOH})$ was $6.22 \$ / \mathrm{kgH}_{2}$ and for the PEC system, it was $8.43 \$ / \mathrm{kgH}_{2}$. Finally, its mutually agreed consensus of the environmental scientist that integration of renewable energy is the way forward to increase energy security and environmental performance by ensuring uninterrupted clean and green energy. Further, this application has the potential to address Pakistan's urgent issues of large-scale surplus wind and solar-generated energy, as well as rising enegry demand.

60 Keywords: Energy security; Energy efficiency; Renewable hydrogen, Green economic indicators; Renewable energy 


\section{1. Introduction}

63 Pakistan has severe electricity crisis; for example, the energy demand-supply deficit in Pakistan

64 is roughly 5500-6000 MW, and full blackouts occur 12-18 hours per day. The Pakistani government spent $\$ 9$ billion in 2008 and 2009 to close the troubling difference between electricity demand and availability, which placed a strain on the country's economy (Iqbal et al. 2019b),(Anh Tu et al. 2021). Furthermore, emerging countries are affected by climate change problems correlated with global warming; for example, Pakistan's temperature has risen dramatically in recent decades (Chien et al. 2021). Because of the detrimental impacts of global change, such as drought, increasing sea levels, and decreased crop yields, as well as the resulting impact on health and poverty, these issues are worth investigating. In comparison to fossil fuel oil, several energy sources include high-productivity hydrogen energy with a significant amount of energy, efficient hydrogen production are biomass, solar, and wind (Jahangiri et al. 2020). Currently, conventional energy sources have the majority of Pakistan's energy, contributing to global warming and climate change (IEA, 2016). One of the main environmental threats of the twenty-first century is climate change caused by anthropogenic greenhouse gas (GHG) pollution. The Intergovernmental Panel on Climate Change (Zhao et al. 2019) proposed a variety of options for rapidly reducing GHG pollution. CO2 emissions responsible for $75 \%$ of anthropogenic GHG emissions (Khan and Tariq 2018), but lowering them has the biggest impact on mitigating global warming. Any of these guidelines, such as the use of intermittent green energies, are on target to keep global warming below 2 degrees Celsius. (VRE) (Wang et al. 2020) and (Nawaz et al., 2021; Hashemizadeh et al. 2021). Since Pakistan is the world's sixth-largest nation and has a rapidly increasing population, the negative consequences of climate change may be extreme. Increased energy demand has resulted from increased population and better living conditions (Iqbal et al. 2020). More than 
140 million Pakistanis suffer regular power shortage of 12-18 hours or do not have connections

87 to the national power grid, resulting in an annual candle and kerosene spending of approximately US $\$ 2.3$ billion. Many experts have called for the use of sustainable and indigenous resources to meet expected energy demand; for example, wind and solar have become essential. Researchers (DellaValle and Sareen 2020) concluded in the literature that rising energy demands could encourage environmental laws that support sustainable energy use, since continued use of carbon-based non-renewable sources. Coastal storm waves, warm summers, unpredictable and flooding are only some of the examples. As a result, a variety of mitigation measures have been implemented to mitigate the impacts of environmental destruction (Babar and Ali 2021) which ranks as the world's 12th most endangered country. Pakistan is also at the peak of a country-by-country ranking of climate danger. Climate change has already claimed the lives of thousands of Pakistanis. This amounted to $1.1 \%$ of overall GDP (Alao et al. 2020). As a result, quantifying and qualifying the potential economic and environmental benefits of generating sustainable hydrogen solely from wind power is

100 significant (Dhiman and Deb 2020). Many research have investigated the architecture and application of sustainable hydrogen systems using different quantitative and computational methods in an effort to establish an optimum energy balance. According to (Bamisile et al. 2021a), hydrogen can outperform necessitate the carbon-free energy systems. Estimation of power and equipment capability and economic assessment. During the construction phase, equipment costs, especially electrolyser costs, are the most significant.

Wind generated renewable hydrogen, sources is adopted for $100 \%$ renewable integration.

107 It will help developing countries improve their energy self-sufficiency and stability, as well as reduce carbon emissions, by systematically broadening their energy portfolio and reducing their dependence (Iqbal et al. 2019a). Hydrogen dioxide, like all natural gas and oil outlets,

110 does not occur in nature. Water (Tolliver et al. 2019), wood, coal, methane, and biological 
111 sources (Taghizadeh-Hesary et al. 2020) may all be used to extract hydrogen. In order to

112 produce hydrogen from these current supplies, the resources expended must be abundant and

113 sufficient on a continuous basis. Fuel cell-powered applications, on the other hand, have been

114 produced but are currently prohibitively costly(Hou et al. 2019). However, with further

115 research and development, these inventions are expected to reach a cost-effective spectrum.

116 When fossil resources become scarce, hydrogen fuel-cell cars are anticipated to supplant

117 conventional gasoline vehicles. Currently, hydrogen processing using wind energy in the

118 electrolysis phase is thought to emit the least amount of greenhouse gas pollution of any

119 hydrogen production method. Furthermore, of all green energy sources, wind-generated power

120 has the lowest cost per kWh (Sun, et al., 2020).

121 The contribution of this paper lies in the following aspects, (i) Our key aim is to identify the most cost-effective method for producing sustainable hydrogen from electricity produced by wind turbines. We have measured the wind power potential and economic viability of wind generated renewable hydrogen to initiate the feasibility of clean fuel (Mohsin, Kamran, Nawaz,

125 Hussain, \& Dahri, 2021). (ii) We have also measured electrolysis cost of wind generated 126 reenwable hydrogen. We have also measured the relative efficiency of the given renewable energy source for hydrogen production which is calculated based on their respective variables. (iii) This study's outcomes can be generalized for policymaking in developing contries such as Paksitan, which owned the same environment, climate, economic, and energy characteristics

130 of economic and environmental vulnerability. As there is a considerable gap in the literature of 131 hydrogen energy feasibilities for developing economies, the current study will fill the literature gap regarding methods, techniques, and evaluation processes of hydrogen energy project feasibility from different angles. (iv) The wind generated renewable hydrogen production and

134 levlized cost of reenwable hydrogen production has been evaluated since it is the only near135 term choice in the scale considered. The study measures the production and supply cost of wind 
136 generated reenwable hydrogen. The net costs of the delivery chains was estimated in the

137 viability report. The costs of delivery are often compared to on-site hydrogen development

138 through water electrolysis, which is an alternate method of supplying hydrogen to industrial

139 hydrogen consumers. The distribution costs are limited by the expense of on-site

140 development.We have proposed a policy framework for policy akers and decision makers

141 based on achieved outcomes.

142 Rest of the paper is organzised as follows, section 2 provides the wind power potential,

143 section 3 explains the methodlogy, section 4 decribes the results and discussion while section

1444 concludes the study.

\section{2. Wind Power Potential and Energy Security}

146 The increased usage of green energy would help to establish a carbon-free energy zone while

147 also reducing the volatile existence of the clean energy market, which faces the greatest

148 obstacle to ensuring a constant supply due to its erratic nature (Nasir et al. 2020) and (Chien et

149 al. 2021). Wind energy generation has recently been the cheapest of all alternative energy

150 sources. Around a decade earlier, (Khodabandehloo et al. 2020) concluded that photovoltaic

151 energy generation is normally more costly than wind energy systems. However, there hasn't

152 been much research in this region. The ability to produce hydrogen solely from wind energy

153 through electrolysis has gotten a lot of attention around the world. Despite possessing a large

154 amount of resources, Pakistan has made little attempt, which prompted the current study (Sha

155 et al. 2020).

156 Pakistan is a South Asian country with wind speed is nearly constant in certain parts of

157 Pakistan, and the proportion of windy region is determined using the total land area. The

158 average installed energy per square kilometer of wind power field is projected by traditional

159 calculations to be 5 MW in order to assess the output of wind power (Duc Huynh et al. 2020). 
160 Table 1 shows the cumulative capacity of wind resource evaluation in numerical terms. As a

161 result, the overall ability of wind energy generation in this area is estimated to be about 349

$162 \mathrm{GW}$.

163 Table.1 Wind resource classification

\begin{tabular}{lccrccl}
\hline Wind Class & 1 & 2 & 3 & 4 & 5 & Total \\
\hline Resource Potential & Moderate & Good & Excellent & Excellent & Excellent & \\
Wind Area (km2) & 43,265 & 18,219 & 5320 & 2514 & 545 & 69,863 \\
(\%) of Total Area & 5.61 & 2.36 & 0.69 & 0.33 & 0.07 & 9.06 \\
Installable Capacity & & & & & & \\
$(\mathrm{MW})$ & 216,325 & 91,095 & 26,600 & 12,570 & 2725 & 349,315 \\
\hline
\end{tabular}

164

Pakistan has favorable offshore wind power capacity in addition to onshore wind energy

potential and its use could account for a significant portion of electricity generation.

167 Furthermore, using offshore resources will help Pakistan tackle air pollution. Renewable

168 technology holds a lot of promise and has piqued people's attention. Renewable energy

169 networks reduce economic risk factors and are unaffected by variations in fuel availability and

170 costs (Anser et al. 2020), (Baloch et al. 2020). Geographically, renewable energy are more

171 uniformly spread. To avoid expensive transmission delays, certain solar energy programs may

172 be installed in small units near customer bases. Furthermore, federal legislation in the US

173 power grid have resulted in significant progress and incentives for clean energy production and

174 implementation (Pan et al. 2019). Renewable technology is projected to receive potential

175 consideration in the domestic energy market as our awareness of the environmental effects of

176 fossil fuel combustion grows. The largest impediment to large-scale clean energy deployments

177 right now is the high upfront capital costs compared to traditional power sources. Any

178 renewable energy systems only generate electrical energy, which has a higher value than heat

179 (Babar and Ali 2021). Hydro, wind, photovoltaic, tidal, and ocean resources are among them.

180 Nonetheless, biomass systems that can produce both heat and energy, as well as geothermal

181 and solar systems (Yumei et al. 2021) are all in the research and development stage. 

usually less sold in the market. Renewable technology encourages the introduction of various renewable energy sources, decreases energy imports, lowers the economy's market sensitivity, and offers ways to improve global energy security (Khokhar et al. 2020). Renewable energy sources may also help to improve the efficiency of energy supplies, particularly in areas where grid connectivity is often limited. (Sueyoshi and Yuan 2017) found that a varied energy mix, as well as good management and device architecture, will help to improve security (Jahangiri et al. 2020). Renewable electricity sources including solar and wind are inherently sporadic. Instead of burning fossil resources, renewable energy sources absorb energy from the

191 atmosphere (such as coal, oil, natural gas, uranium). The sun is the ultimate provider of green

192 resources accessible to humanity (Wang et al. 2019), (Yue et al. 2017). The overall radiant energy flux it intercepts from the planet is far greater than existing green energy solutions capture power. Although the theoretically significant volume of energy available, collecting and using this energy in a cost-effective manner remains a challenge. Electricity is becoming a more strategic asset as technical change accelerates and certain industries, such as agriculture and manufacturing, become more mechanized (Bortoluzzi et al. 2021). A systematic evaluation of the use of wind and alternative energy in developed countries is one such solution. Such analyses may be carried out in the framework of a green energy viability study in order to entice prospective investors to invest in the renewable energy market.

\subsection{Brief Literature Review}

(Chien et al. 2021) in China measured the capacity for wind energy production revealed that this area had a peak annual average wind energy density of $429 \mathrm{~W} / \mathrm{m} 2$, indicating that it was an excellent investment prospect. (Bortoluzzi et al. 2021) conducted an economictechnical study in Taiwan to assess the right wind turbines for wind power ventures. They looked at things like annual electricity production, financial metrics, fossil fuel usage reduction, 
207 CO2 reduction, and turbine power factor for this. Finally, the VestasTMV60-850 KW model 208 turbine was recommended as the best choice for the country's central regions. Hydrogen 209 generation capacity from clean energy sources is being investigated (Wu et al. 2021).

210 Renewable resources such as solar energy, geothermal energy, oil palms, and biomass have

211 been identified as potential sources of hydrogen energy. Solar energy production costs are

212 normally 6 to 18 times higher than comparable renewable energy and wind turbine systems, 213 according to the report (Alvarez-Herranz et al. 2017) and (Wu et al. 2021).

214 As a result, it's critical to assess the potential for renewable hydrogen generation from 215 wind energy (Seker and Aydin 2020).Hydrogen dioxide, like all natural gas and oil outlets, 216 does not occur in nature. Hydrogen may therefore be derived from a variety of natural resources, 217 including water, wood, coal, methane, and biological sources. As a result, we developed a novel 218 statistical evaluation of renewable energy indicators in off-grid and remote regions, including 219 wind-generated renewable hydrogen, in order to improve energy security and reduce 220 continuous emission levels in the field. In order to produce hydrogen from these current 221 supplies, the resources expended must be abundant and sufficient on a continuous basis 222 (Tolliver et al. 2019) and (Kakoulaki et al. 2021). The aim of this research is to look at the techno-economics of sustainable hydrogen production utilizing wind energy in various windy locations in Pakistan's Sindh province. The levelized cost of wind energy was also estimated to determine the cost of hydrogen output (Bamisile et al. 2021b) and (Ozturk and Dincer 2021).

\section{Data and Methodology}

Hydrogen production from water electrolysis is also a suitable way to maintain efficiency performance of $80-90 \%$, demonstrates considerable potential in a variety of hydrogenproduction technologies (Bhattacharyya and Bhattacharyya 2019) and (Awaworyi Churchill et 
230 al. 2020). The amount of renewable hydrogen produced from wind energy is provided in the

231 following equation .

232

$$
h=\frac{\eta_{\mathrm{el}} \mathrm{E}_{\mathrm{out}}}{\mathrm{ec}_{\mathrm{el}}}
$$

Where $\mathrm{h}$ is the amount of hydrogen generated, $\mathrm{E}_{\text {out }}$ is the wind electricity input to the

234 electrolyzer for hydrogen production, $\mathrm{ec}_{\mathrm{el}}$ is the electrolysis process performance, which

235 ranges between 80 and $90 \%$, and $\eta_{\mathrm{el}}$ is the electrolyzer energy consumption, which is normally

$2365-6(\mathrm{KWh} / \mathrm{Nm} 3) . \Delta \mathrm{H}=286 \mathrm{~kJ}$ mol-1 is needed for the decomposition of water $(\mathrm{H} 2 \mathrm{O})$ to

237 produce $\mathrm{H} 2$. The ultimate chemical reaction of water electrolysis can be written as:

$$
\mathrm{H}_{2} \mathrm{O} \rightarrow \mathrm{H}_{2}+\frac{1}{2} \mathrm{O}_{2}
$$

239 The charge transfer and enthalpy shift of the reaction determine the thermoneutral voltage $\mathrm{V}_{\mathrm{TH}}$

$$
V_{T H}=\frac{\Delta \mathrm{H}}{2 F}
$$

241 F shows molar charge constant, which is measured in efficiency. In relation to $\mathrm{V}_{\mathrm{TH}}$ of $\mathrm{n}$ number

242 of cells, electrolyzer process performance $\left(\eta_{\mathrm{el}}\right)$ can be measured almost precisely by 243 electrolyzer voltage $\left(\mathrm{V}_{\mathrm{el}}\right)$,

$$
\eta_{e l} \approx \frac{1.48 n}{V_{e l}}
$$

Overvoltage is caused by a variety of failure factors, including physical, electrochemical, and

247 transmission-related losses, which increase in proportion to current density (Ogura 2020).

248 When attached to a wind turbine, the electrolyzer can run at a variety of current and power 249 speeds.

250 The total cell reaction response can be said to be the number of the two half reactions while 251 voltages of the reduction $\left(E_{r e d}^{\mathrm{o}}\right)$ and oxidation $\left(E_{o x}^{\mathrm{o}}\right)$. half-reactions.

$$
E_{\text {cell }}^{0}=E_{(o x)}^{0}+E_{(r e d)}^{0}
$$


252 The capacity of an isolated half-cell cannot be calculated explicitly. As a comparison, the 253 normal hydrogen half-reaction was chosen and given a standard reduction potential of exactly $2540.000 \mathrm{~V}$,

$$
2 H_{(1 M)}^{+}+2 e^{-}=H_{2(1 a t m)}\left(E_{\text {red }}^{o}=0.00 \mathrm{~V}\right)
$$

And

$$
\begin{aligned}
& \text { (Anode) } \mathrm{Zn}_{(s)} \rightarrow \mathrm{Zn}_{(a q)}^{2+}+2 e^{-} \text {(oxidation) } E_{\mathrm{Zn} / \mathrm{Zn} n^{2+}}^{o}=0.76 \mathrm{~V} \\
& \text { (Cathode) } \mathrm{Cu}^{2+}+2 e^{-} \rightarrow C u_{(s)} \cdot\left(\text { reduction) } E_{\mathrm{Cu}^{2+} / \mathrm{Cu}}=0.34 \mathrm{~V}\right.
\end{aligned}
$$

256 Therefore,

$$
\begin{aligned}
& E_{\text {cell }}^{o}=E_{(o x)}^{o}+E_{(r e d)}^{o} \\
& E_{\text {cell }}^{o}=0.76+0.34 \mathrm{~V} \\
& E_{\text {cell }}^{o}=1.10 \mathrm{~V}
\end{aligned}
$$

The levelized cost of energy is a useful metric for comparing the unit costs of various technologies over their economic Levlized cost of electricity (LCOE). The LOCE approach is often used as a benchmarking technique to compare the costs of various electricity production technologies. Wind power economics are determined by a variety of factors, including net construction costs, energy generation, repair and operating costs, location selection, and wind turbine characteristics. The ratio of increasing NPV of total costs (PVC) to total energy (E tot) generated through the device is used to estimate the wind per unit cost $(\mathrm{C} \mathrm{W})$.

$$
\mathrm{C}_{\mathrm{W}}=\frac{P V C}{E_{t o t}}
$$

\subsection{Electrolysis Cost}

Many previous studies have suggested an electrolyzer economic model, in which the electrolyzer expenditure consists of three major costs: cash, operational, repair, and replacement. The overall cost of the electrolysis cell is determined by the amount of hydrogen 
that can be generated. The electrolyzer capital cost is determined by the necessary rate of hydrogen supply (Kazmi et al. 2019). The efficient electrolyzer performance and the average real capital cost per $\mathrm{kWh}$ at nominal output are calculated as,

272

273

$$
\begin{aligned}
& C_{e l e, u}=\frac{M_{H_{2}} K_{e l, t h}}{8760 \cdot f \eta_{u}} \\
& C_{\text {ele }, u}=\frac{M_{H_{2}} K_{e l, t h}}{8760 \cdot f \eta_{u}}
\end{aligned}
$$

where $\left(C_{e l e, u}\right)$ is the electrolyzer unit rate, $\mathrm{f}$ is the power factor, and $K_{e l, t h}$ is the electrolyser's energy requirement. The comparison case assumes that the electrolyzer unit cost is $\$ 368 / \mathrm{kWh}$, which is the goal amount. We believe that annual maintenance costs and repair costs electrolyzer has a seven-year operating period. We must measure the running costs of the chosen locations in order to investigate their economic evaluation. The per-unit expense $(\$ / \mathrm{kWh})$ of wind power production must be estimated for chosen locations. Table 2 presents the component involves the wind turbine's explicitly specified power cost $(\mathrm{C} 1)$, as well as miscellaneous costs (C2), construction costs (C3), operating and repair costs (C4), (C5) shows inverter costs and (C6) shows battery bank costs,

Table.2 Rated power costs of wind turbine

\begin{tabular}{ccc}
\hline $\mathrm{Pt}(\mathrm{kW})$ & Caspec $(\$ / \mathrm{kW})$ & Average $($ CASPEC) $(\$ / \mathrm{kW})$ \\
\hline$>200$ & 1150 & $700-1600$ \\
$20-200$ & $1250-2300$ & 1775 \\
$<20$ & 2600 & $2200-3000$ \\
\hline
\end{tabular}

It can be determined using the following formula,

$$
P V C=I+C_{2}\left(\frac{1+i}{r-1}\right)\left[1-\left(\frac{1+i}{1+r}\right)^{L}\right]-S\left(\frac{1+i}{1+r}\right)^{L}
$$

The total cost can be measured as,

$$
C_{T}=\mathrm{PVC}+C_{5}+C_{6}
$$

The expense of operating and maintaining a wind turbine is estimated to be $25 \%$ of the annual investment cost. Scrap is thought to be worth ten \% of the annual investment expense (Shahzad et al. 2020). The investment expense (IC) is calculated as follows:

$$
\mathrm{I}_{\mathrm{c}}=\mathrm{C}_{\mathrm{ASPEC}}+\mathrm{P}_{\mathrm{r}}
$$


293 where $C_{\text {ASPEC }}$ shows an average cost of per unit $\mathrm{kW}$ and $\mathrm{P}_{\mathrm{r}}$ deterrmine the rated power cost of 294 a wind turbine (Bangalore and Patriksson 2018).

$$
C_{\mathrm{cu}}==\frac{\text { Total cost }}{\text { Annual average yield }}
$$

Table. 3 Selected wind turbine specifications

\begin{tabular}{ccccccc}
\hline $\begin{array}{c}\text { Wind Turbine } \\
\text { Model }\end{array}$ & $\begin{array}{c}\text { Rated } \\
\text { Power } \\
(\mathrm{KW})\end{array}$ & $\begin{array}{c}\text { Hub Height } \\
(\mathrm{m})\end{array}$ & $\begin{array}{c}\text { Cut in } \\
\text { Speed }(\mathrm{m} / \mathrm{s})\end{array}$ & $\begin{array}{c}\text { Cut Out } \\
\text { Speed }(\mathrm{m} / \mathrm{s})\end{array}$ & $\begin{array}{c}\text { Rotor } \\
\text { Diameter }(\mathrm{m})\end{array}$ & $\begin{array}{c}\text { Swept Area } \\
(\mathrm{m} 2)\end{array}$ \\
\hline $\mathrm{GW}-109 / 2500$ & 2500 & 50 & 3 & 25 & 109 & 9516 \\
\hline
\end{tabular}

297 The hydrogen production cost $C_{\mathrm{H}_{2}}$ is a major economic indicator has been taken as follows,

$$
\boldsymbol{C}_{\boldsymbol{H}_{2}} \frac{\mathrm{C}_{\mathrm{W}}+\mathrm{C}_{\text {ele }}}{\mathrm{M}_{\mathrm{H}_{2}} \cdot \mathrm{T}}
$$

299 where $\mathrm{C}_{\mathrm{W}}$ and $\mathrm{M}_{\mathrm{H}_{2}}$ represents the energy cost (\$) and per year green hydrogen production respectively. Internationally, the constraint on green hydrogen production, particularly through wind energy from electrolysis, has gotten a lot of attention. Pakistan, on the other hand, just makes use of a small portion of this potential, ignoring the resource's usability. In the light of the topic above, this evaluation adds to a reduction in non-renewable energy source reliability

304 (Cook et al. 2019). This investigation examines the atmosphere in almost every part of Pakistan while also serving as a condensed study of domestic demand for green wind-produced hydrogen.

$$
Z=\max _{e, h} \sum_{t \in 0}^{T}\left(P_{t}^{e} e_{t}^{g r i d}+P_{t}^{h} h_{t}\right) \tau
$$

$$
W_{t}=e_{t}^{g r i d}+e_{t}^{h}, \forall_{\mathrm{t}} \in \mathrm{T}
$$

$$
h_{t}=a \cdot e_{t}^{h}, \forall_{\mathrm{t}} \in \mathrm{T}
$$

$$
h_{t}, e_{t}^{g r i d}, e_{t}^{h} \geq 0 \quad \forall_{\mathrm{t}} \in \mathrm{T}
$$

$311 \boldsymbol{P}_{\boldsymbol{t}}^{\boldsymbol{h}}(\$ / \mathrm{kgH} 2)$ and $\boldsymbol{P}_{\boldsymbol{t}}^{\boldsymbol{h}}(\$ / \mathrm{kWhe})$ are the negligible hydrogen and consumer power costs,

312 respectively. The $\mathbf{h}_{\mathbf{t}}\left(\$ / \mathrm{kgH}_{2} / \mathrm{h}\right)$ hourly hydrogen production and power supplied from wind 313 energy provided to the national lattice, ht grid, duplicate these costs $(\mathrm{kWe})$. With the set $\mathrm{T}, \mathrm{t}$ 314 displays a certain period and includes the time interval (60 minutes). (2) At time t, 
$315 \boldsymbol{e}_{t}^{\boldsymbol{h}} \operatorname{grid}(\mathrm{kWe})$, the power generated from wind energy provided to the national grid, $\boldsymbol{e}_{\boldsymbol{t}}^{\boldsymbol{h}}(\mathrm{kWe})$,

316 and the power spent for renewable hydrogen production at e th grid (kWe) have been divided

$317(\mathrm{kWe})$. At time $\mathrm{t}$, limitation (3) depicts the production of green hydrogen using wind energy.

318 The option considerations, according to limitation (4), are non-negative genuine numbers and

319 the day-ahead market power price. $\boldsymbol{P}_{\boldsymbol{t}}^{\boldsymbol{h}}$ grid energy is being provided to the K.E., ht hourly

320 hydrogen production, $\boldsymbol{P}_{\boldsymbol{t}}^{\boldsymbol{h}}$ and the low hydrogen cost, and $\boldsymbol{e}_{\boldsymbol{t}}^{\boldsymbol{h}}$ electricity scavenge deal is planned.

321 The space-time-yield (STY) is a measure of how much output can be generated per unit of

322 volume and time. This number is used to figure out how much each LOHC's reactor costs. It is 323 determined by equation (21).

$$
S T Y=\frac{n_{A} \chi_{A} M_{A}}{V_{A 0} t_{R}}
$$

324 With $\mathrm{n}_{\mathrm{A}}=$ Maximum mole flow of the target product $(\mathrm{A})$ per mole of source material $\left(\mathrm{A}_{0}\right)$ $\chi_{\mathrm{A}}=$ Equilibrium conversion $\mathrm{M}_{\mathrm{A}}=$ Molar mass $\mathrm{V}_{\mathrm{A} 0}=$ Volume of one mole source material, including solvents $t_{R}=$ Reaction time

\subsection{Methodology for Calculating Supply Cost of Reneable Hydrogen}

$$
\text { The amount of deliveries expected each day would be determined by the hydrogen }
$$
demand and the truck's payload:

$$
\text { required deliveries per day }\left(\text { day }^{-1}\right)=\frac{\text { Hydrogen demand }\left(\mathrm{kg} \mathrm{day}^{-1}\right)}{\text { Net hydrogen payload }(\mathrm{kg})}
$$

333 The total trip time will be determined by the following factors: unloading/loading (drop-

334 off/pick-up) times, transportation size, and average speed: 
337 Theoretical maximum number of trips for each truck per day can then be calculated:

$$
\text { max \# of trips per day per truck }\left(\text { day }^{-1} \text { truck }^{-1}\right)=\frac{24 h}{\text { total trip time }(h)}
$$

The required number of trucks was determined based on the number of deliveries required to satisfy demand, as well as the theoretical potential number of trips per truck would make in one day, taking into account truck availability,

$$
\text { required } \# \text { of trucks }=\frac{\text { required trips per day }}{\text { max } \# \text { of trips per day per truck } * \text { truck availability (\%) }}
$$

This number has been rounded to the next higher integer. Since rounding up, the lowest number of trips per day per truck that satisfies the hydrogen requirement is used in the study, which allows for non-integer amounts. For eg, a truck making 0.5 trips every day might deliver any other day. Three times as many trailers as trucks are needed for $\mathrm{GH}_{2}$ distribution options.

The trucks will wait until the tanker trailer is unloaded and then filled in the case of LOHC transport. As a result, LOHC base distribution necessitates the use of storage tanks. The cost of storage was included in the hydrogen production costs. The appropriate number of trucks and trailers, as well as their investment costs (IC) and capital recovery factors (CRF), were used to measure annualized investment costs for truck fleets (ICann,trucking),

$$
I C_{\text {ann,trucking }}=(\# \text { of trucks }) \times C R F_{\text {truck }} \times I C_{\text {truck }}+(\# \text { of trailers }) \times
$$

$$
C R F_{\text {trailer }} \times I C_{\text {trailer }}
$$

354 Operation and maintenance costs (in $\$ / \mathrm{kg} \mathrm{H}_{2}$ ) were calculated from the specified variable (VC) and fixed costs (FC) of the trucks and trailers (Tahir and Asim 2018) and (Gasser 2020): 
salary of the driver and delivered amount of useable hydrogen per truck:

$$
S C_{\text {trucking,personnel }}=\frac{(\text { total trip time }) \times(\text { hourly salary })}{\text { Delivered useable hydrogen per truck }}
$$

Drive distance, fuel usage, fuel price, and delivered volume of usable hydrogen will all be

used to quantify real delivery costs due to truck fuel consumption (Mohsin et al. 2018) and

363 (Iqbal et al. 2019b):

$$
S C_{\text {trucking, fuel }}=\frac{2 \times(\text { one }- \text { way distance }) \times \text { FuelConsumption } \times \text { FuelPrice }}{\text { Delivered useable hydrogen per truck }}
$$

The total specific hydrogen delivery cost from trucking then becomes:

$$
S C_{\text {trucking }}=\frac{I C_{\text {trucking }} \times C R F_{\text {trucking }}}{\text { Delivered useful hydrogen per year }}+S C_{\text {trucking,O\&M }}+S C_{\text {trucking,Fuel }}+
$$

$$
S C_{\text {trucking,personnel }}
$$

The energy and hydrogen rates are set in the cases determining the worth of variable power and hydrogen supply, and the discount rate is determined to result in an NPV of zero at the end of the plant lifespan. This discount rate represents the anticipated return on investment from the construction and operation of the various plants.

$$
N P V=\sum_{i=1}^{t} \frac{A C E_{i}}{(1+i)^{t}}
$$

The method used to calculate the expense of $\mathrm{CO}_{2}$ avoidance as seen in Eq. (31). (COCA). The levelized cost of energy is represented by LCOE, and the real $\mathrm{CO}_{2}$ emissions of the plant is represented by $\mathrm{E}$. The plant with $\mathrm{CO}_{2}$ capture (Case 1) is denoted by the subscript $\mathrm{CC}$, while the plant without $\mathrm{CO}_{2}$ capture (Case 1 ) is denoted by the subscript ref.

\subsection{Data}

Wind speed data for various cites has been collected from metrological department of 
380 Laboratory USA (NREL) while the data for interestrate inflation and other economic indcators

381 has been collcted from National Bank of Pakistan (NBP) and State Bank of Pakistan( SBP).

\section{4. Results and Discussion}

\subsection{Green Hydrogen Production}

384

In this experiment, we used an electrolyzer with a $5\left(\mathrm{kWh} / \mathrm{Nm}^{3}\right)$ energy intake and a $90 \%$

efficient rectifier. The formula for converting hydrogen formed by normal cubic meters into

kilograms is $11.13\left(\mathrm{Nm}^{3}\right)$. Table. 3 shows the findings of a study of annual hydrogen output at

eight different locations and the capicity factor.

Table. 3 Wind statistics

\begin{tabular}{lllllrlrr}
\hline & Katti & \multicolumn{2}{c}{ Jamshor } & \multicolumn{2}{c}{ DHA } & \multicolumn{2}{c}{ Nooriaba } \\
sites & Bandar & Talhar & Gharo & o & Baghan & Karachi & Golarchi & d \\
\hline C.F & 0.29 & 0.25 & 0.27 & 0.45 & 0.43 & 0.42 & 0.4 & 0.5 \\
RE/kW & 2100955 & 1638804 & 1697772 & 2237963 & 2070573 & 2044817 & 1919930 & \\
h & 2 & 3 & 4 & 0 & 3 & 9 & 8 & $3.05 E+08$ \\
H2-Kg & 393437 & 306892 & 317934 & 419094 & 387747 & 382924 & 359537 & 570524 \\
\hline
\end{tabular}

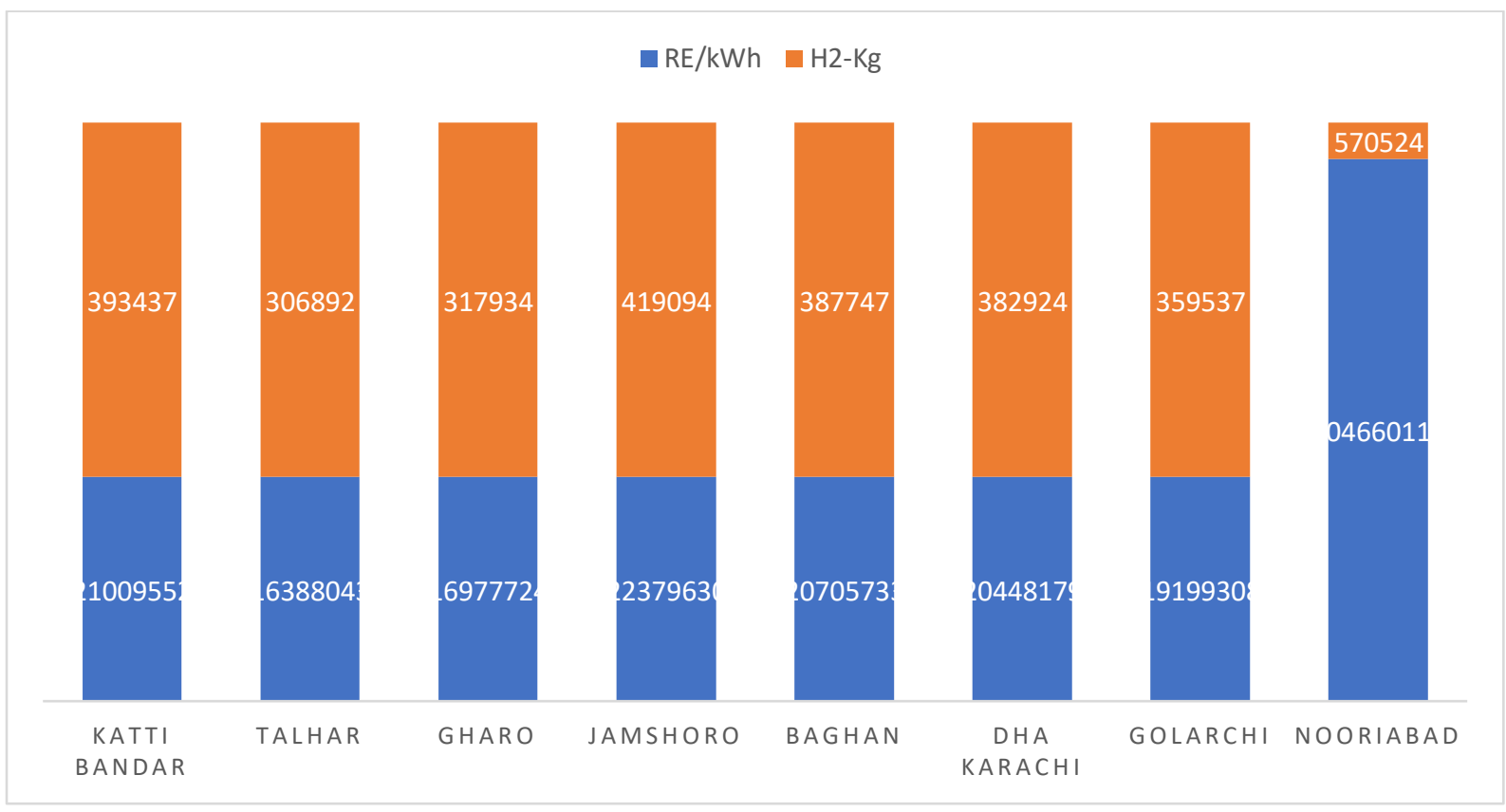

Figure. 1 renewable energy and hydrogen production

To generate energy, which is needed to create hydrogen, there must be a lot of wind.

393 Annually, each car needs around $97 \mathrm{~kg}$ of hydrogen, (figure.1). Where, $9.5 \mathrm{~kg}$ of hydrogen is 
equivalent to $25 \mathrm{~kg}$ of gasoline by comparing the two energy sources. The explanation for this is because petroleum fuel has a capacity four times that of hydrogen fuel. Furthermore,

396 Pakistan's cumulative wind-generated electricity capability is 119,410 MW. Additionally, 397 transportation oil usage may be used to generate energy, alleviating fuel shortages. Total 398 distribution costs for the $2.5 \mathrm{MW}(1800 \mathrm{~kg} / \mathrm{day})$ and $10 \mathrm{MW}$ (7200 kg/day) cases were 399 determined to be $1.0-3.1 \$ / \mathrm{kg}$ and $0.7-2.8 \$ / \mathrm{kg}$, correspondingly. For transport distances of $400 \quad 50-150 \mathrm{~km}$, levelized cost of electricity and composite $\mathrm{GH}_{2}$ are almost similarly efficient due 401 to low venture costs for dehydrogenation reactors, whereas $300 \mathrm{~km}$ favors levelized cost of 402 electricity. The cost of delivery using levelized cost of electricity should not escalate 403 significantly as the distance traveled increases. In any case, delivery using 200 bar steel bottle 404 containers is not the most cost-effective alternative, and the costs rise sharply with distance 405 traveled. The expense of the fleet ranges from 0.3 to 1.0 million euros for levelized cost of electricity shipping, 1.8-7.8 million euros for steel bottle tanks, and 1.4-7.2 million euros for composite cylinders.

\section{$408 \quad 4.2$ Economic Analysis}

409 The economic analysis is based on such assumptions, such as construction and operational 410 costs accounting for $25 \%$ of annual wind turbine expenditure and a wind turbine's existence 411 being 20 years. Though installation costs are 5\%, investment costs are $10 \%$. As a result, at the 412 final supply stage for the provided proposed locations, average price increases with regard to 413 the intent of consumption. Further considerations presumed that the capital expense of 414 sustainable hydrogen production is $\$ 0.027 / \mathrm{kg}$, which covers direct, secondary, and 415 maintenance costs. For ease of comparison, the leveled water supplying rate is estimated to be 416 about $\$ 4.1 /$ ton of water. As a result, the electrolysis system's capital charging ratio ranges from $417 \quad 0.10$ to 0.115 (figure 2). 
419 ranges from $\$ 4.02 / \mathrm{kg}-\mathrm{H}_{2}$ to $\$ 4.310 / \mathrm{kg}-\mathrm{H}_{2}$. Annualized capital investment is the main

420 determinant of green hydrogen production prices as compared to annual expenditures such as

421 raw material procurement costs and plant running costs. The literature on sustainable energy

422 systems shows that the economic burden imposed by large capital expenditures. Also, through

423 adapting, marketing, preparing, timing, and expanding markets and demand, a practical

424 strategy for planning excess electricity will boost the economics of renewable energy

425 production. Table. 4 presents the results of cost of electricity and Renewable hydrogen

426 generation. The economic incorporation of hydrogen reveals that the cost of production varies

427 between $\$ 4.9$ and $\$ 5.1$ per kilogram.

428 Table.4 Cost of electricity and Renewable hydrogen

\begin{tabular}{lrrrrrrrr}
\hline Sites & \multicolumn{1}{l}{$\begin{array}{l}\text { Katti } \\
\text { Bandar }\end{array}$} & \multicolumn{1}{c}{ Talhar } & \multicolumn{1}{c}{ Gharo } & Jamshoro & Baghan & \multicolumn{1}{c}{ KHA } \\
C.F & 0.29 & 0.25 & 0.27 & 0.45 & 0.43 & 0.42 & 0.4 & 0.5 \\
Electricity & & & & & & & & \\
(\$/kWh) & 0.084 & 0.086 & 0.085 & 0.081 & 0.081 & 0.082 & 0.082 & 0.08 \\
H2 Price/kg-H2 & 4.304 & 4.315 & 4.31 & 4.221 & 4.221 & 4.221 & 4.221 & 4.002 \\
\hline
\end{tabular}

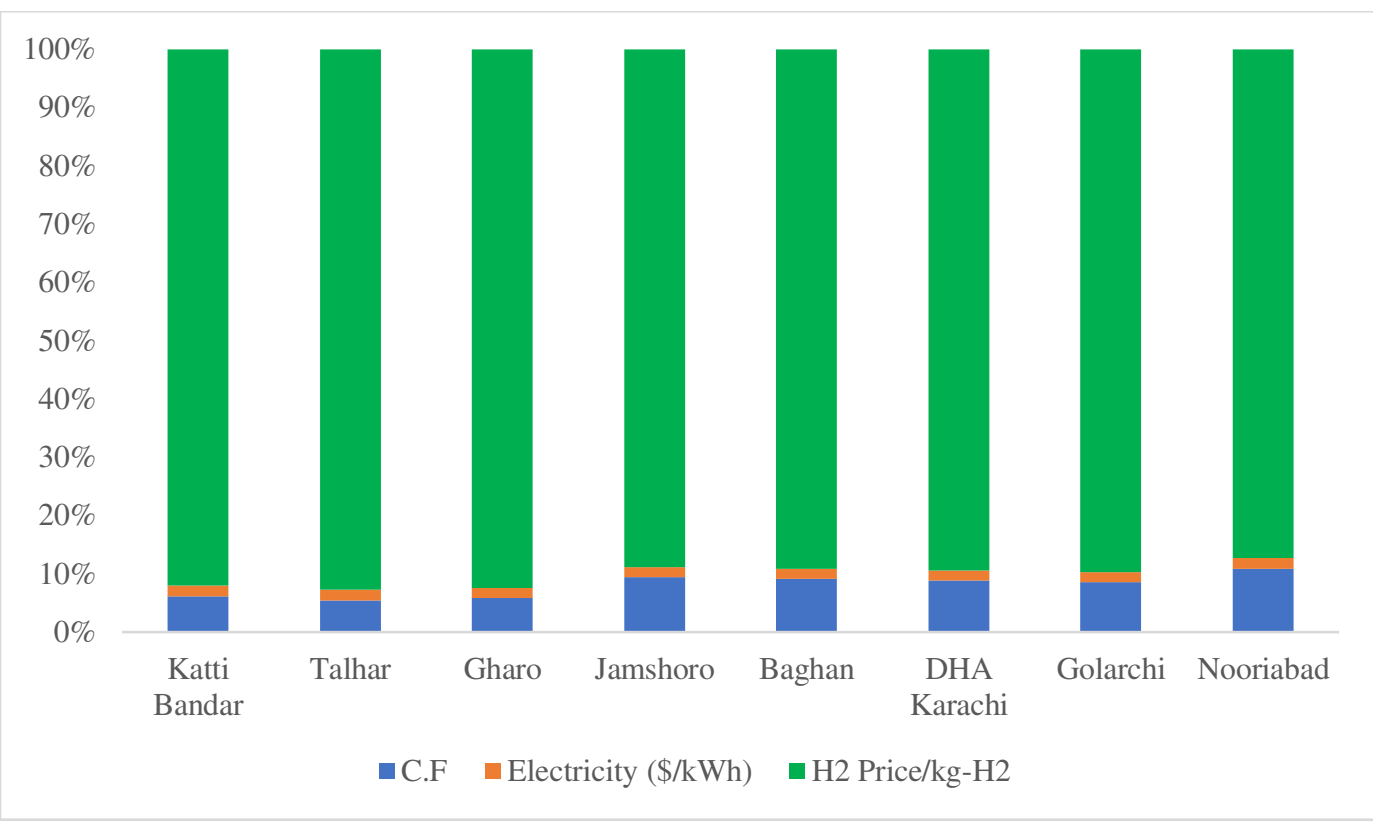




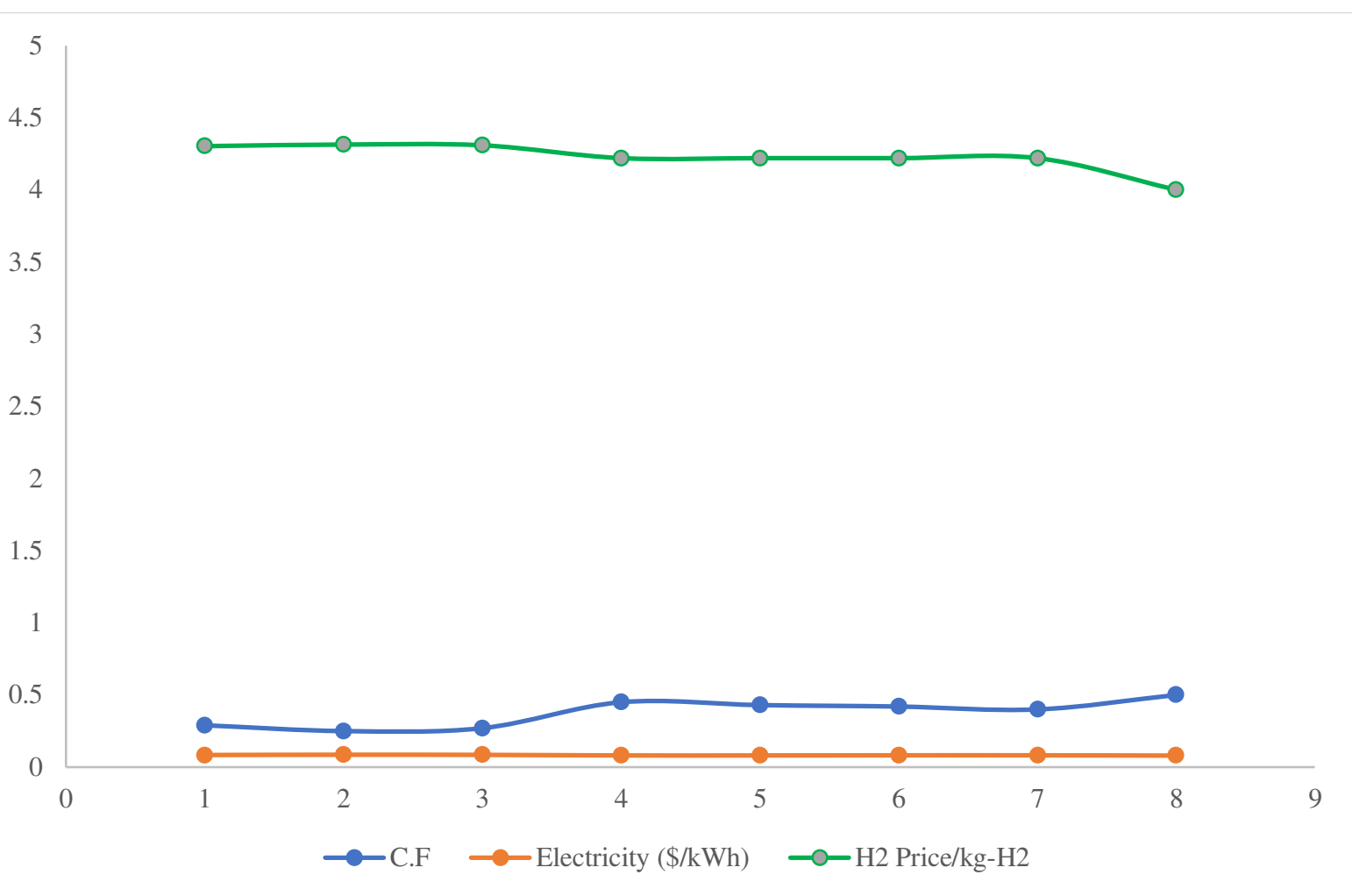

Figure.3 Capacity factor and price of $\mathrm{H}_{2}$

Since all expenditures are the same, the priority process has little bearing on the system's

CAPEX; it's just a separate scheduling technique. In terms of OPEX, there is a disparity in the volume of hydrogen sold and hence in the costs of transporting hydrogen. However, transportation charges for excess hydrogen are not included since they are distributed to third parties that choose to purchase this hydrogen. Because of this distribution, the OPEX and CAPEX for all priority systems are the same. The power rate, which includes prices for energy

441 from the solar park and the grid, is the only factor that varies. The fuel costs in the Power-to-

$442 \mathrm{H}_{2}$ scheme with heat as a target are $260 \mathrm{k} \$$ per year, although they have now increased to 360

$443 \mathrm{k} \$$ per year, since both heat and hydrogen are purchased from the grid.

444 In the hydrogen case, the output prices for heat and hydrogen shift. Since the heat system's 445 reliability has reduced and more energy from the grid is purchased at a higher price than from 446 the solar park, the heat price has increased by $1.1 \$ / \mathrm{GJ}$ to $27.1 \$ / \mathrm{GJ}$. With the same investment 447 costs, hydrogen demand grows from 90 to 125 tonnes a year. As a result, the price of hydrogen 
supply falls from 5.4 to $4.6 \$ / \mathrm{kg}$ (figure 3). The price of water should not adjust significantly.

449 When hydrogen is prioritized inside the system, gross annual costs per household are 1,715 $\$ /$ year, vs 1,785 \$/year when heat is prioritized. In terms of yearly costs per home, the favorable impacts on hydrogen production costs balance out the detrimental effects of higher heat production rates. The key explanation for the lower costs is that, with equal expenditures, more hydrogen is generated, resulting in a higher electrolyser ability factor.

\subsection{Grid Electricty and wind generated renewable hydrogen prices}

The wind generated reenwable electrolysis system's techno-economic study yields an

LCOH of $6.22 \$ / \mathrm{kgH}_{2}$. The costs are split down into the wind and electrolyzer sections for the

first and second bars, respectively, to demonstrate the ratio of these two parts. The new global movement toward lowering GHG pollution, is focused on solid science assertions about the impact of an increasingly evolving atmosphere on natural, social, and economic sustainability.

Experts are now warning of the dangers of global climate change caused by human-caused

GHG pollution. $\mathrm{CO}_{2}$ pollution increased by $4.2 \%$ a year between 1999 and 2004. Furthermore, according to the same study, Pakistan is responsible for $0.2 \%$ of global carbon emissions, or around 9.3 tons of $\mathrm{CO}_{2}$ per human. As a result, Pakistan has the potential to enact measures to reduce greenhouse pollution, such as an emissions exchange scheme. To address the threat of climate change, well-defined emission-reduction strategies and environmental legislation are essential. Pakistan is among the world's poor largest oil producer and has seen a substantial increase in GHG emissions, especially $\mathrm{CO}_{2}$, as a result of increasing petroleum output and related sales (which account for around $95 \%$ of export earnings and contribute more than 54\% of Pakistan's GDP).

Pakistan's main contributors to GHG emissions are oil and cement production, which,

471 like most other countries with large increases in greenhouse emissions, can be linked to both economic and industrial development. The usage of petroleum products as fuels in many 
473 refining, industrial, and transportation fields is one of Pakistan's major causes of air pollution.

$474 \mathrm{CO}_{2}$ is primarily generated through the burning of different fuels in the power generation sector $475(38 \%)$, transportation (20\%), and industry (8\%), with other industries accounting for the 476 remaining 34\%. Various toxic or toxic gases (primarily carbons, hydrocarbons, acid, and 477 nitrogen oxides) are emitted from oil fields and refineries, and can have a negative impact on 478 the local residential and marine areas. In 2010, two-thirds of the world's electricity was 479 generated by burning fossil fuels, and Pakistan emitted around 60 million tons (Mt) of $\mathrm{CO}_{2}$, up 480 from 50 million tons (Mt) in 2002. This was mostly due to rising energy demand. Since the 481 sum of $\mathrm{CO}_{2}$ pollution per unit of energy differs based on the fuel type (coal, oil, or natural gas), 482 the shift toward higher natural gas consumption should help to dramatically reduce $\mathrm{CO}_{2}$ 483 emissions in the long run. $\mathrm{CO}_{2}$ emissions are projected to more than double in the coming years 484 as a result of rising energy growth, hitting about $104 \mathrm{Mt}$ in 2030. Over the forecast timeframe, 485 annual average growth in pollution is estimated to be $3.3 \%$. However, because of the shift to gas-fired power plants, this is smaller than the initial estimate (3.6\% rise in demand).

487 Table.5 Grid electricity prices

\begin{tabular}{ll}
\hline Grid average electricity price & $60 \$ / \mathrm{MW} \mathrm{h}$ \\
Mid-load price premium & $10-40 \$ / \mathrm{MW} \mathrm{h}$ \\
Hydrogen sales price & $\$ 1.35 / \mathrm{kg}$ \\
Capacity factor & $45 \%$ \\
$\mathrm{H}_{2}$ capacity factor & $45 \%$ \\
First year capacity factor & $30 \%$ \\
$\mathrm{CO}_{2}$ price & $30-100 \$ /$ ton \\
\hline
\end{tabular}

488

489 Table.5 shows that the cost of the electrolyzer is higher than that of the wind device, at 3.92 $490 \$ / \mathrm{kgH}_{2}$ and $2.30 \$ / \mathrm{kgH}_{2}$ respectively. Without maximizing the size of these two plant materials, 491 the difference is much wider. More wind power deivices were introduced as part of the 492 optimization process to reduce the amount of electrolyzer modules, resulting in a power factor 
493 rise from $28 \%$ to $31 \%$. As a result, the photovoltaic panel's surface area rose by $4 \%$, while the

494 electrolyzer section's scale decreased by $11 \%$. Since there is already demand for economies of scale and hence a substantial rise in output rate, it is possible that the electrolyzer's costs would

496 drop significantly within the next several years. The third bar depicts the total device costs,

497 demonstrating that module costs account for a significant portion of the total.

\subsection{Comparitive Discussion}

In some cases, the purpose of energy security is to protect the poor from fluctuations in commodity prices (Šprajc et al. 2019). Others have emphasized the importance of protecting the economy from disruptions in the supply of energy services by increasing commodity prices during periods of scarcity (Arminen and Menegaki 2019). For some, the goal of energy security is to reliably provide fuel, while the role of nuclear energy is to increase security (Amin and 504 Bernell 2018). Results reveals that Sindh province has a potential demand for renewable hydrogen of 454, 192, $000 \mathrm{~kg}$ and that renewable hydrogen production ability is sufficient.

Except for a few areas in Sindh province's interior, wind-generated renewable hydrogen. Furthermore, provinces with strong wind-energy capacity, such as Sindh's interior and the coastal areas of Sindh and Baluchistan, also have few options for a hydrogen mandate. Renewable corridors in Sindh and Baluchistan can be reconciled analytically to ensure renewable hydrogen generation and use (Liu et al. 2018). Sindh province is home to nearly all

511 wind power schemes, and its geological characteristics make it ideal for producing green 512 hydrogen for ZEVs and fuel cell electric vehicles.

513 Energy costs is increasingly making wind-generated renewable hydrogen more appealing.

514 In addition, the impact of K-Electric-produced electricity rates are minor. Wind-generated 515 green hydrogen already has a marginal price of US\$4.30/kg- $\mathrm{H}_{2}$. As a result, annual wind516 generated renewable hydrogen demand rises with time, owing to improved sales, which enables 517 additional wind power plants to be built, thus increasing the ability of wind-generated 
518 renewable hydrogen output. (Khan et al. 2018) and (El Khatib and Galiana 2018). Hydrogen

519 could also be supplied by cryogenic tanker trucks, or it could be liquefied and transported by

520 pipelines. Pipelines, , are only cost efficient for vast quantities or short lengths, but they are

521 seldom used to maximize the efficiency of by-product hydrogen. Due to substantially complex

522 cargoes (4000-4500 kg), liquefaction will allow renewable generated hydrogen to be trucked

523 more effectively over long distances. The hydrogen liquefaction method, on the other hand, is

524 both capital and energy intensive. Boil-off damages are often caused by the shipping and

525 handling of liquid hydrogen (Roddis et al. 2018). Owing to the immaturity of the process, the

526 investment costs for dehydrogenation and hydrogenation reactors are somewhat unpredictable.

527 For "large-scale" green hydrogena production, (Krejčí and Stoklasa 2018) used costs of 260

528 and $40 \$ / \mathrm{kWH}_{2}, \mathrm{LHV}$, respectively. Basic costs for hydrogenation and dehydrogenation reactors for a $\mathrm{MWH}_{2}, \mathrm{LHV}$ facility were 252 and $368 \$ / \mathrm{kWH}_{2}, \mathrm{LHV}$, respectively. As a result, cost estimates vary greatly.

531 In addition, there is considerable inconsistency in the prices of hydrogenation and

532 dehydrogenation reactors. Teichmann, for example, calculated hydrogenation reactor costs to

533 be slightly higher than dehydrogenation reactor costs, while $\mathrm{xxx}$ estimated reactor costs to be

534 far closer together. (Al Garni and Awasthi 2017) thought the dehydrogenation reactor was more costly, although Reu thought the same. Pakistan might reduce its crude oil demand by 600 billion barrels a day if it implemented green hydrogen power production. It will be

537 necessary to will the existing $\mathrm{CO}_{2}$ emissions of 166298450 tons in this sense. Results shows

538 the cost of carbon emissions at different constrained prices, which could be affordable as

539 compared to the cost of ecological theft. Since the yield of green hydrogen is dependent on the

540 nature of usable wind, which differs and is difficult to forecast, using the greater degree of wind

541 output poses a suspension problem. The electricity market faces considerable inconsistency as

542 a result of this variation, as it becomes difficult to balance supply and demand. In the case of 
543 traditional power terminals, shifting demand levels will render market power costs extremely

544 volatile, posing additional difficulties for businesses who depend on transmitting it (Maleki et 545 al. 2017) and (Valasai et al. 2017).

\section{5.Conclusion and Policy Implication}

547 The current study measured the wind powe power potential and economic viability of 548 wind generated renewable hydrogen to initiate the feasibility of clean fuel. The study's 549 outcomes can be generalized for policymaking in developing contries such as Paksitan. which 550 owned the same environment, climate, economic, and energy characteristics of economic and environmental vulnerability. Different electrolyzer systems exist to generate effective hydrogen via the electrolysis phase. When the minimum price of hydrogen exceeds US\$2.99/kg kg- $\mathrm{H}_{2}$, green hydrogen demand rises as well. In the Pakistani energy sector, however, it is commercially beneficial since the marginal price of sustainable hydrogen is US $\$ 3.92 / \mathrm{kg}-\mathrm{H}_{2}$. Furthermore, due to the efficiencies of the hydrogen conversion mechanism, wind energy could generate approximately 0.85 billion $\mathrm{kg}$ of hydrogen in Pakistan, which could meet the country's $22 \%$ demand for hydrogen.

The findings show that the marginal prices of renewable hydrogen, respectively US $\$ 1 / \mathrm{kg}$ $\mathrm{kg}-\mathrm{H} 2$ and US $\$ 4 / \mathrm{kg} \mathrm{kg-H} 2$, have a considerable impact on annual hydrogen demand, and that

560 a significant rise in renewable hydrogen production. The results have not been taken into account. Furthermore, lower renewable hydrogen prices (e.g., US $\$ 2 / \mathrm{kg}$ ) have a relative impact on renewable hydrogen demand. Annual wind-generated sustainable hydrogen output is 563 dependent. The performance of an energy conversion electrolyzer device will have a big impact

564 on the amount of renewable hydrogen generated by wind. According to the findings, an 565 electrolyzer device with a $75 \%$ energy efficiency 
distribution entity since 2012 due to consolidation. There are three Rental Power Projects to choose from (RPPs). Pakistan's gross installed power generating capacity will exceed $3.4 \mathrm{GW}$ in 2020 , compared to a requirement of $2.5 \mathrm{GW}$ from primary customers which can only carry out 2.2 GM energy during peak hours requirement, it would be unable to close the $3000 \mathrm{MW}$ deficit difference. As a result of machine inefficiency, NTDC has $17.53 \%$ line losses and KEL has $25.30 \%$. As a consequence, there is a significant difference between production and demand [41]. Furthermore, the majority of hydroelectric plants are operating at $50 \%$ potential and are affected by seasonal water supply. The working capability of thermal plants that contribute more than $60 \%$ of overall power production is a pitiful $65 \%$. Notably, increasing generating capability and relying too heavily on hydrocarbon supplies does not help to mitigate energy shortages where usable resources are underutilized or misused [42]. Increasing the country's power generating capacity by constructing new plants is an unworkable option for increasing availability. Repairing improperly run generation plants and dysfunctional transmission and dispatch networks, on the other hand, will accomplish the same goal.

Distribution losses ranged from $9.47 \%$ to $33.40 \%$, and no DISCOs were able to hit NEPRA's loss goals, with some also seeing an improvement over the previous year. Another issue is the lack of long-term, organized, and integrated policymaking, as shown by the fact that programs were started. The schemes that were found to be infeasible in the middle of the project. Due to geopolitics, despite its significant hydropower capacity, it was not given priority.

587 No technological adaptation abused local capital, and after signing the MOU for thermal plants, the China Pakistan Economic Corridor is now responsible for all projects.

589 The Pakistani government, on the other hand, wants to raise wind-generated electricity and has suggested many locations. Pakistan will meet its national demand and export clean electricity by converting its power system to wind and solar energy. Several pathways for

592 hydrogen development, including thermal and reenwable hydrogen which is now the most 
593 widely utilized process due to its reliability and low cost. In comparison, hydrogen production

594 using fossil fuels generated hazardous gases (e.g., GHGs) during the manufacturing phase.

595

596 Ethical Approval and Consent to Participate

597 N/A

We do not have any individual person's data in any form.

\section{Authors Contribution}

601 Wu Baijun: Conceptualization, Data curation, Methodology, Writing - original draft.

602 Bingfeng Zhai: Data curation, Visualization. Huaizi Mu: Visualization, supervision, editing.

603 Xin Peng : editing. Chao Wang: review. Ataul Karim Patwary: Final review \& editing and

604 software

605 Funding

606 This research did not receive any specific funding from public, commercial or non-profit sector

607 funding agencies.

608 Competing interest statement 
The data that support the findings of this study are openly available on request.

612

\section{Refrences}

614 Al Garni HZ, Awasthi A (2017) Solar PV power plant site selection using a GIS-AHP based

615 approach with application in Saudi Arabia. Appl Energy.

616 https://doi.org/10.1016/j.apenergy.2017.10.024

617 Alao MA, Ayodele TR, Ogunjuyigbe ASO, Popoola OM (2020) Multi-criteria decision based

618 waste to energy technology selection using entropy-weighted TOPSIS technique: The

619 case study of Lagos, Nigeria. Energy 201:117675.

620 https://doi.org/https://doi.org/10.1016/j.energy.2020.117675

621 Alvarez-Herranz A, Balsalobre-Lorente D, Shahbaz M, Cantos JM (2017) Energy innovation 622 and renewable energy consumption in the correction of air pollution levels. Energy

$623 \quad$ Policy. https://doi.org/10.1016/j.enpol.2017.03.009

624 Amin M, Bernell D (2018) Power sector reform in Afghanistan: Barriers to achieving

625 universal access to electricity. Energy Policy 123:72-82.

626 https://doi.org/10.1016/j.enpol.2018.08.010

627 Anh Tu C, Chien F, Hussein MA, et al (2021) Estimating role of Green Financing on Energy

628 Security, Economic and Environmental Integration of BRI member countries. Singapore $629 \quad$ Econ Rev. https://doi.org/10.1142/s0217590821500193

630 Anser MK, Iqbal W, Ahmad US, et al (2020) Environmental efficiency and the role of energy 631 innovation in emissions reduction. Environ Sci Pollut Res 27:29451-29463.

632 https://doi.org/10.1007/s11356-020-09129-w

633 Arminen H, Menegaki AN (2019) Corruption, climate and the energy-environment-growth nexus. Energy Econ. https://doi.org/10.1016/j.eneco.2019.02.009

635 Awaworyi Churchill S, Inekwe J, Ivanovski K, Smyth R (2020) Stationarity properties of per 636 capita $\mathrm{CO} 2$ emissions in the OECD in the very long-run: A replication and extension 
analysis. Energy Econ 90:104868. https://doi.org/https://doi.org/10.1016/j.eneco.2020.104868

Babar AHK, Ali Y (2021) Enhancement of electric vehicles' market competitiveness using fuzzy quality function deployment. Technol Forecast Soc Change 167:120738. https://doi.org/https://doi.org/10.1016/j.techfore.2021.120738

Baloch ZA, Tan Q, Iqbal N, et al (2020) Trilemma assessment of energy intensity, efficiency, and environmental index: evidence from BRICS countries. Environ Sci Pollut Res 27:34337-34347. https://doi.org/10.1007/s11356-020-09578-3

Bamisile O, Babatunde A, Adun H, et al (2021a) Electrification and renewable energy nexus in developing countries; an overarching analysis of hydrogen production and electric

Bangalore P, Patriksson M (2018) Analysis of SCADA data for early fault detection, with application to the maintenance management of wind turbines. Renew Energy 115:521-

Bamisile O, Obiora S, Huang Q, et al (2021b) Impact of economic development on CO2 vehicles integrality in renewable energy penetration. Energy Convers Manag 236:114023. https://doi.org/https://doi.org/10.1016/j.enconman.2021.114023 532. https://doi.org/10.1016/J.RENENE.2017.08.073

Bhattacharyya SC, Bhattacharyya SC (2019) Energy Data and Energy Balance. In: Energy

$$
\text { Economics. pp 7-40 }
$$

Bortoluzzi M, Correia de Souza C, Furlan M (2021) Bibliometric analysis of renewable energy types using key performance indicators and multicriteria decision models. Renew Sustain Energy Rev 143:110958. https://doi.org/https://doi.org/10.1016/j.rser.2021.110958

Chien FS, Kamran HW, Albashar G, Iqbal W (2021) Dynamic planning, conversion, and management strategy of different renewable energy sources: A Sustainable Solution for Severe Energy Crises in Emerging Economies. Int J Hydrogen Energy. https://doi.org/10.1016/j.ijhydene.2020.12.004

Cook WD, Ramón N, Ruiz JL, et al (2019) DEA-based benchmarking for performance 
evaluation in pay-for-performance incentive plans. Omega 84:45-54

668

669

670

671

672

673

674

675

676

677

678

679

680

681

682

683

684

685

686

687

688

689

690

691

692

693

694 695 https://doi.org/10.3390/pr7040196

696 Jahangiri M, Shamsabadi AA, Mostafaeipour A, et al (2020) Using fuzzy MCDM technique

DellaValle N, Sareen S (2020) Nudging and boosting for equity? Towards a behavioural economics of energy justice. Energy Res Soc Sci.

$$
\text { https://doi.org/10.1016/j.erss.2020.101589 }
$$

Dhiman HS, Deb D (2020) Fuzzy TOPSIS and fuzzy COPRAS based multi-criteria decision making for hybrid wind farms. Energy 202:117755.

$$
\text { https://doi.org/https://doi.org/10.1016/j.energy.2020.117755 }
$$

Duc Huynh TL, Burggraf T, Nasir MA (2020) Financialisation of natural resources \& instability caused by risk transfer in commodity markets. Resour Policy.

https://doi.org/10.1016/j.resourpol.2020.101620

El Khatib S, Galiana FD (2018) Investigating Emission Regulation Policy in the Electricity Sector: Modeling an Oligopolistic Electricity Market under Hourly Cap-and-Trade. Energy Econ. https://doi.org/10.1016/j.eneco.2018.05.037

Gasser P (2020) A review on energy security indices to compare country performances. Energy Policy 139:111339. https://doi.org/10.1016/j.enpol.2020.111339

Hashemizadeh A, Ju Y, Bamakan SMH, Le HP (2021) Renewable energy investment risk assessment in belt and road initiative countries under uncertainty conditions. Energy 214:118923. https://doi.org/https://doi.org/10.1016/j.energy.2020.118923

Hou Y, Iqbal W, Shaikh GM, et al (2019) Measuring energy efficiency and environmental performance: A case of South Asia. Processes 7:325. https://doi.org/10.3390/pr7060325

Iqbal W, Altalbe A, Fatima A, et al (2019a) A DEA approach for assessing the energy, environmental and economic performance of top 20 industrial countries. Processes 7:902. https://doi.org/10.3390/PR7120902

Iqbal W, Fatima A, Yumei H, et al (2020) Oil supply risk and affecting parameters associated with oil supplementation and disruption. J Clean Prod 255:.

https://doi.org/10.1016/j.jclepro.2020.120187

Iqbal W, Yumei H, Abbas Q, et al (2019b) Assessment of wind energy potential for the 99 production of renewable hydrogen in Sindh Province of Pakistan. Processes 7:196. 
697

698

699

700

701

702

703

704

705

706

707

708

709

710

711

712

713

714

715

716

717

718

719

720

721

722

723

724

725

726

to find the best location in Qatar for exploiting wind and solar energy to generate hydrogen and electricity. Int J Hydrogen Energy 45:13862-13875. https://doi.org/https://doi.org/10.1016/j.ijhydene.2020.03.101

Kakoulaki G, Kougias I, Taylor N, et al (2021) Green hydrogen in Europe - A regional assessment: Substituting existing production with electrolysis powered by renewables. Energy Convers Manag 228:113649. https://doi.org/https://doi.org/10.1016/j.enconman.2020.113649

Kazmi H, Mehmood F, Tao Z, et al (2019) Electricity load-shedding in Pakistan: Unintended consequences, opportunities and policy recommendations. Energy Policy 128:411-417. https://doi.org/10.1016/j.enpol.2019.01.017

Khan KS, Tariq M (2018) Wind resource assessment using SODAR and meteorological mast - A case study of Pakistan. Renew Sustain Energy Rev 81:2443-2449. https://doi.org/10.1016/J.RSER.2017.06.050

Khan MTI, Ali Q, Ashfaq M (2018) The nexus between greenhouse gas emission, electricity production, renewable energy and agriculture in Pakistan. Renew Energy 118:437-451. https://doi.org/10.1016/j.renene.2017.11.043

Khodabandehloo M, Larimi A, Khorasheh F (2020) Comparative process modeling and techno-economic evaluation of renewable hydrogen production by glycerol reforming in aqueous and gaseous phases. Energy Convers Manag 225:113483. https://doi.org/https://doi.org/10.1016/j.enconman.2020.113483

Khokhar M, Hou Y, Rafique MA, Iqbal W (2020) Evaluating the social sustainability criteria of supply chain management in manufacturing industries: A role of BWM in MCDM. Probl Ekorozwoju 15:185-194

Krejčí J, Stoklasa J (2018) Aggregation in the analytic hierarchy process: Why weighted geometric mean should be used instead of weighted arithmetic mean. Expert Syst Appl. https://doi.org/10.1016/j.eswa.2018.06.060

Liu H, Li J, Long H, et al (2018) Promoting energy and environmental efficiency within a positive feedback loop: Insights from global value chain. Energy Policy 121:175-184. https://doi.org/10.1016/j.enpol.2018.06.024

Maleki A, Pourfayaz F, Hafeznia H, Rosen MA (2017) A novel framework for optimal 
photovoltaic size and location in remote areas using a hybrid method: A case study of eastern Iran. Energy Convers Manag. https://doi.org/10.1016/j.enconman.2017.09.061

Mohsin, M., Kamran, H.W., Nawaz, M.A., Hussain, M.S., \& Dahri, A.S. (2021). Assessing

Mohsin M, Rasheed AK, Saidur R (2018) Economic viability and production capacity of wind generated renewable hydrogen. Int. J. Hydrogen Energy

Nasir MA, Balsalobre-Lorente D, Huynh TLD (2020) Anchoring inflation expectations in the face of oil shocks \& in the proximity of ZLB: A tale of two targeters. Energy Econ. https://doi.org/10.1016/j.eneco.2020.104662

Nawaz, M. A., Seshadri, U., Kumar, P., Aqdas, R., Patwary, A. K., \& Riaz, M. (2021). Nexus between green finance and climate change mitigation in N-11 and BRICS countries: empirical estimation through difference in differences (DID) approach. Environmental Science and Pollution Research, 28(6), 6504-6519.

Ogura Y (2020) Policy as a “porter” of RE component export or import? Evidence from PV/wind energy in OECD and BRICS. Energy Econ 86:. https://doi.org/10.1016/j.eneco.2019.104630

Ozturk M, Dincer I (2021) An integrated system for ammonia production from renewable hydrogen: A case study. Int J Hydrogen Energy 46:5918-5925. https://doi.org/https://doi.org/10.1016/j.ijhydene.2019.12.127

Pan X, Pan X, Jiao Z, et al (2019) Stage characteristics and driving forces of China's energy efficiency convergence_-an empirical analysis. Energy Effic 12:2147-2159. https://doi.org/10.1007/s12053-019-09825-8

Roddis P, Carver S, Dallimer M, et al (2018) The role of community acceptance in planning outcomes for onshore wind and solar farms: An energy justice analysis. Appl Energy. https://doi.org/10.1016/j.apenergy.2018.05.087

Seker S, Aydin N (2020) Hydrogen production facility location selection for Black Sea using entropy based TOPSIS under IVPF environment. Int J Hydrogen Energy 45:1585515868. https://doi.org/https://doi.org/10.1016/j.ijhydene.2019.12.183 
Sha Y, Kang C, Wang Z (2020) Economic policy uncertainty and mergers and acquisitions: Evidence from China. Econ Model. https://doi.org/10.1016/j.econmod.2020.03.029

Shahzad K, Jianqiu Z, Hashim M, et al (2020) Impact of using information and communication technology and renewable energy on health expenditure: A case study from Pakistan. Energy 204:. https://doi.org/10.1016/j.energy.2020.117956

Šprajc P, Bjegović M, Vasić B (2019) Energy security in decision making and governance Methodological analysis of energy trilemma index. Renew Sustain Energy Rev 114:109341. https://doi.org/10.1016/j.rser.2019.109341

Sueyoshi T, Yuan Y (2017) Social sustainability measured by intermediate approach for DEA environmental assessment: Chinese regional planning for economic development and pollution prevention. Energy Econ 66:154-166. https://doi.org/10.1016/j.eneco.2017.06.008

Sun, H., Awan, R. U., Nawaz, M. A., Mohsin, M., Rasheed, A. K., \& Iqbal, N. (2020). Assessing the socio-economic viability of solar commercialization and electrification in south Asian countries. Environment, Development and Sustainability, 1-23.

Taghizadeh-Hesary F, Rasoulinezhad E, Yoshino N, et al (2020) The energy-pollution-health nexus: A panel data analysis of low- And middle-income asian countries. Singapore Econ Rev. https://doi.org/10.1142/S0217590820430043

Tahir ZR, Asim M (2018) Surface measured solar radiation data and solar energy resource assessment of Pakistan: A review. Renew. Sustain. Energy Rev. 81:2839-2861

Tolliver C, Keeley AR, Managi S (2019) Green bonds for the Paris agreement and sustainable development goals. Environ Res Lett. https://doi.org/10.1088/17489326/ab1118

Valasai G Das, Uqaili MA, Memon HR, et al (2017) Overcoming electricity crisis in Pakistan: A review of sustainable electricity options. Renew Sustain Energy Rev 72:734-745. https://doi.org/10.1016/j.rser.2017.01.097

Wang Y, Wen Z, Li H (2020) Symbiotic technology assessment in iron and steel industry based on entropy TOPSIS method. J Clean Prod 260:120900. https://doi.org/https://doi.org/10.1016/j.jclepro.2020.120900

Wang Z, Hao H, Gao F, et al (2019) Multi-attribute decision making on reverse logistics 
based on DEA-TOPSIS: A study of the Shanghai End-of-life vehicles industry. J Clean Prod 214:730-737. https://doi.org/10.1016/j.jclepro.2018.12.329

Wu Y, Zhang T, Gao R, Wu C (2021) Portfolio planning of renewable energy with energy storage technologies for different applications from electricity grid. Appl Energy 287:116562. https://doi.org/https://doi.org/10.1016/j.apenergy.2021.116562

Yue S, Yang Y, Pu Z (2017) Total-factor ecology efficiency of regions in China. Ecol Indic 793 73:284-292. https://doi.org/10.1016/j.ecolind.2016.09.047

794 Yumei H, Iqbal W, Nurunnabi M, et al (2021) Nexus between corporate social responsibility 795 and firm's perceived performance: evidence from SME sector of developing economies. Environ Sci Pollut Res 28:2132-2145. https://doi.org/10.1007/s11356-020-10415-w

Zhao H, Guo S, Zhao H (2019) Comprehensive assessment for battery energy storage systems based on fuzzy-MCDM considering risk preferences. Energy 168:450-461.

799 https://doi.org/https://doi.org/10.1016/j.energy.2018.11.129

800 
Figures

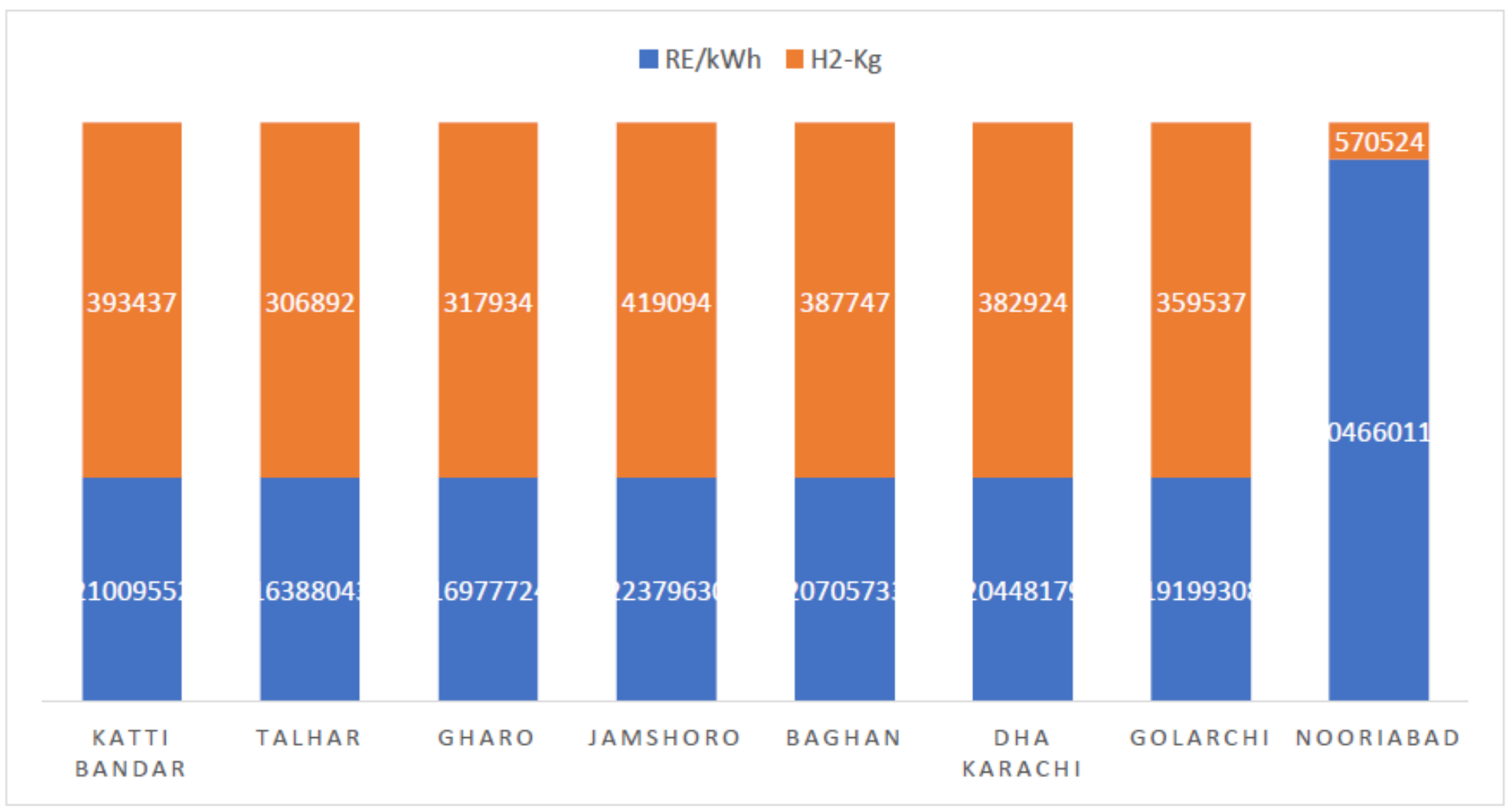

Figure 1

Renewable energy and hydrogen production 


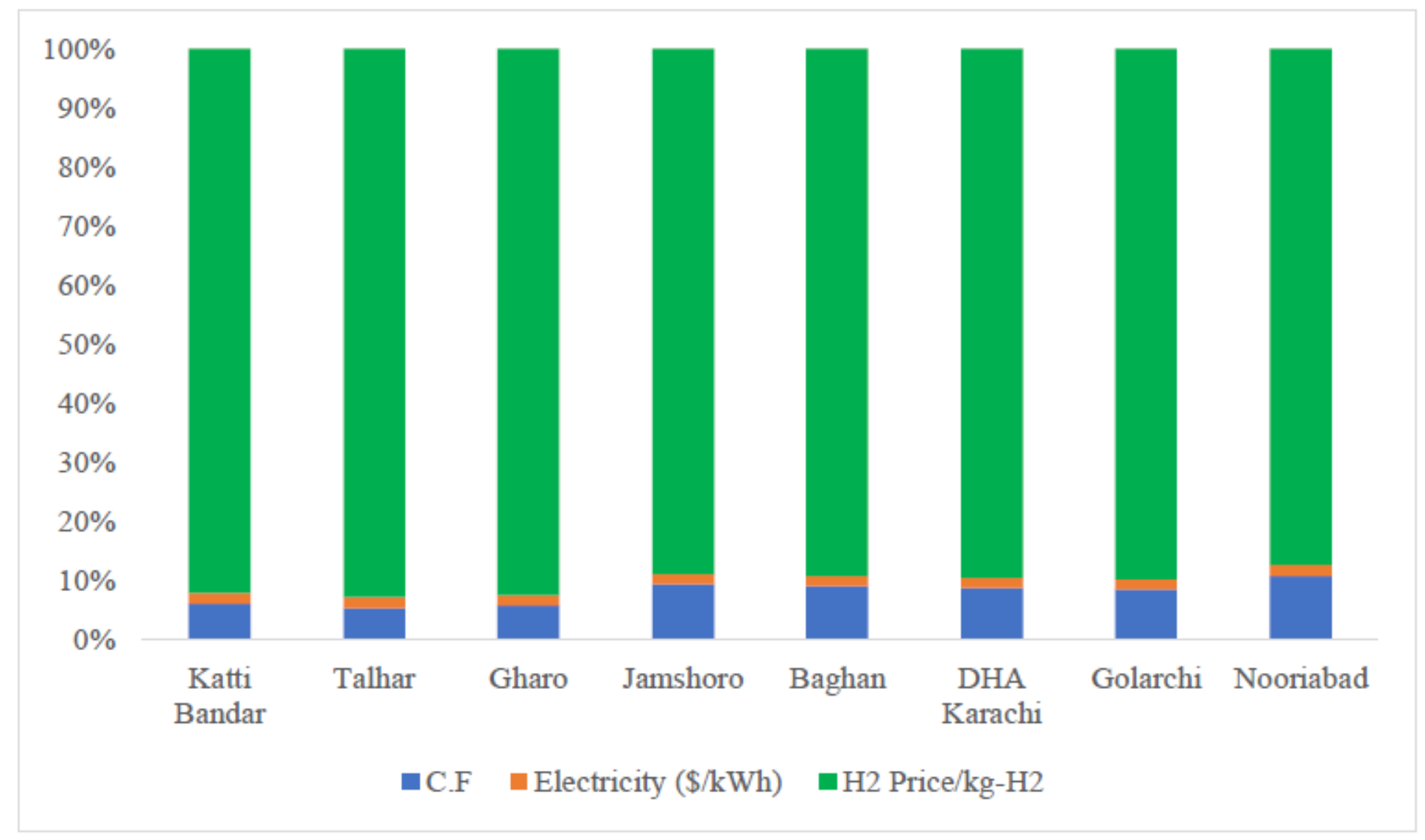

Figure 2

Capacity factor and electricity prices 


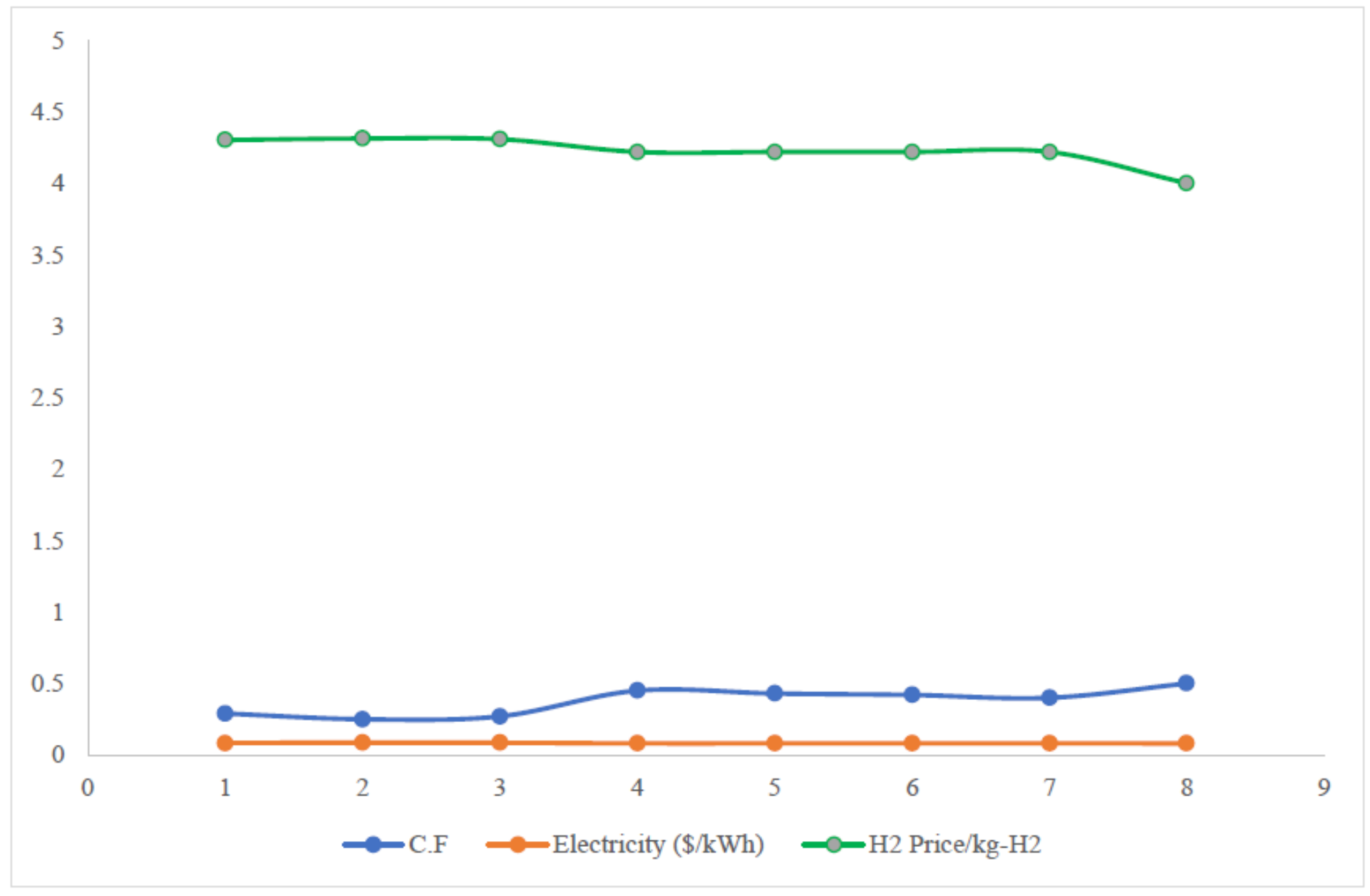

Figure 3

Capacity factor and price of $\mathrm{H} 2$ 